\title{
SELECTED ISSUES RESULTING FROM THE IMPLEMENTATION OF THE MARKETS IN FINANCIAL INSTRUMENTS DIRECTIVE (MIFID) OF THE EUROPEAN PARLIAMENT AND OF THE COUNCIL IN THE POLISH REGULATORY FRAMEWORK
}

\section{Introduction}

There are several reasons to discuss the problems of the regulations for standardization of operations of the markets in financial instruments, the so-called MiFID. ' Undoubtedly it is important to stress that it is a new regulation which has only been in effect in Poland from this year and which has so far been quite rarely addressed by our juristic writing. ${ }^{2}$ The most important issue, however, is the scope of amendments introduced by this regulation to the Polish regulatory framework, in particular, in the aspect of customer protection on the market in financial instruments. This issue is gaining a specific importance in terms of reality in Poland, taking into account the difficulties which, in connection with the world economic crisis, some entrepreneurs, who trade in FX derivatives have experienced. ${ }^{3}$ Given this situation, one may give careful consideration (taking into account the scope of changes arising from the new regulation) as to whether an earlier transposition thereof would have served to limit the losses suffered by entrepreneurs. ${ }^{4}$

Referring to this issue, it is necessary to raise here a proposal, which will form the basic assumption of this article, i.e. the solutions introduced could provide an increase in the protection afforded to customers in the market in financial instruments. It is

MiFID is an English-language abbreviation of the Markets in Financial Instruments Directive 2004/39/EC of the European Parliament and of the Council and executive regulations.

2 Issues on outsourcing have been analyzed.

3 The conclusions made by the Polish Financial Supervision Authority (KNF) were presented in the document "Basic Conclusions of the Analysis of Businesses Engagement in FX Derivatives - the Polish Financial Supervision Authority" dated 11 March 2009. In the KNF's opinion, approximately $15-20 \%$ of entrepreneurs could suffer losses from $\mathrm{FX}$ derivatives transactions.

It is however interesting that in the said document (page 3), KNF confirmed that in this aspect the banks - which, irrespective of the lack of implementation of the MiFID Directive into the Polish regulatory framework, have introduced the amendments arising there from to their internal regulations - acted properly. 
necessary, however, to make reservation to the effect that the genuine scale of their impact will be greatly determined by both the quality of relevant internal regulations drawn up by financial institutions, and the accuracy in application thereof.

The basic objective of the new regulation is to increase the protection of customers in the market in financial instruments by the determination of specified standards of the financial services market. However, it is necessary to stress that this objective is being implemented comprehensively, because the assumption of the said regulation is the establishment of the unified legal framework for financial markets that operate within the framework of the EU member-states, Iceland, Norway, and Lichtenstein. The directive introduces standards to such issues as: conditions of activity related to the businesses' provision of investment services (also including additional services), organization of financial institutions, requirements concerning their reporting and the principles of transaction transparency. In order to achieve these objectives, financial institutions were obliged to introduce stringent internal provisions in the scope of: compliance with provisions, risk management, complaint examination, personal transactions, outsourcing, and the management of conflict of interest. $^{5}$

For the purpose of making correct deliberations (including, in particular, the verification of the proposal raised hereinabove), it is necessary to apply certain structural assumptions. It is obvious that the scope of problems analyzed is quite broad, therefore the main task will be to show the most essential (in the author's opinion) changes in the scope of standards that are binding on the provision of financial services in Poland, which standards, are viewed from the standpoint of customer protection. New obligations imposed on financial institutions will be presented herein below, which obligations will be divided into three categories. The first category will incorporate problems related to the classification (segmentation) of new and existing customers. Thereafter, the issues related to information obligations, also including procedures followed as early as on the stage of commencement and provision of services, will be presented. Finally, obligations of the individual analysis and customer evaluation will be indicated.

It is, however, necessary to first remind ourselves that the above conceptualization is tricky, because it incorporates new problems, which have yet to be properly addressed in Polish doctrine and which as yet are not supported by any existing practice. Therefore, our analysis will be based almost exclusively on the legislative materials transposing the provisions of the EU directive to the Polish regulatory framework. struments amending Council Directives 85/611/EEC and 93/6/EEC and Directive 2000/12/EC of the European Parliament and of the Council and repealing Council Directive 93/22/EEC, Official Journal L 145, 30/04/2004 P. 0001-0044, point 5, page 2 . 


\section{Legal basis in European law and transposition into Polish law}

In order to provide our considerations in an orderly manner, it is first necessary to specify the legal basis for the binding force of MiFID, which legal basis incorporates the following acts of law:

1) Directive 2004/39/EU of the European Parliament and of the Council of 21 April 2004 on markets in financial instruments amending Council Directives 85/611/EEC and 93/6/EEC and Directive 2000/12/EC of the European Parliament and of the Council and repealing Council Directive 93/22/EEC, Official Journal L 145, 30/04/2004 P. 0001-0044, referred to as MiFID I.

2) Commission Directive 2006/73/EC of 10 August 2006, implementing Directive 2004/39/EC of the European Parliament and of the Council as regards organizational requirements and operating conditions for investment firms and defined terms for the purposes of that Directive, Official Journal 09/08/2007 L 209, Supplement No. 38 (referred to as MiFID II).

3)Commission Regulation (EC)No. 1287/2006 of 10 August 2006, implementing Directive 2004/39/EC of the European Parliament and of the Council as regards recordkeeping obligations for investment firms, transaction reporting, market transparency, admission of financial instruments to trading, and defined terms for the purposes of the Directive, Official Journal 09/08/2007 L 209, Supplement No. 38.

The term of transposition by Poland, as the EU member-state, of the provisions of Directive 2004/39/EU of the European Parliament and of the Council arises from Art. 41 of the Commission Directive 2006/73/EU, according to which this act was to become effective on 1 November 2007. ${ }^{6}$ Poland, however, like many other European states, implemented the Directive after a long delay. ${ }^{7}$ On 4 September 2008, Sejm (the Polish Parliament) adopted the Law Amending the Law on the Turnover in Financial Instruments and Some Other Legal Acts, which law was forwarded by the Polish President to the Constitutional Tribunal for the verification of its compliance with the Polish Constitution in the scope of the National Bank of Poland's obligation to dispose of the stock in Krajowy Depozyt Papierów Wartościowych S.A. (the National Depository of Securities) held thereby. In the opinion of the Polish President, provisions on this obligation breach the constitutional principle of the central bank's independence. On 16 July 2009, the Constitutional Tribunal rendered

According to the provisions of Art. 11 and Art. 34.5-34.6, this Act became effective on 1 June 2007. Taking into account, however, a 9-months adjustment period, the Directive shall become effective in the Polish regulatory framework by a deadline of 9 November 2009. 
the judgment on the case (file No. K p 4/08) ${ }^{8}$ whereby it declared that the imposition on the National Bank of Poland of the obligation to dispose of the stock in Krajowy Depozyt Papierów Wartościowych S.A. is non-constitutional. At the same time, the Constitutional Tribunal declared that challenged Art. 19 is not inseparably associated with the amendment of the Trading in Financial Instruments Act as a whole. Finally, after the above-mentioned provision was removed, the MiFID regulations were introduced into the Polish regulatory framework. The transposition of the said Directive caused the introduction of amendments into a range of legal acts and the most important of these acts were as follows:

1) Trading in Financial Instruments Act of 4 September 2008, and other acts on trading in financial instruments of 29 July, and some other acts (Dz.U. of 2009, No. 165, item 1316).

2) Finance Minister's Ordinance of 20 November 2009, on the manner and conditions of conduct of investment firms, banks, referred to in Art. 70.2 of the Trading in Financial Instruments Act, and of custodian banks (Dz.U. of 2009 No. 204, item 1577),

3) Finance Minister's Ordinance of 23 November 2009, on determination of detailed technical and organizational conditions for investment firms, banks, referred to in Art. 70.2 of the Trading in Financial Instruments Act, and for custodian banks, as well on conditions of brokerage house's evaluation of the internal capital (Dz.U. of 2009, No. 204 item 1579).

\section{Legal analysis of selected issues}

In accordance with the above, the assumption of new regulations is to ensure fair competition in the financial sector, to guarantee relevant standards, and primarily to ensure a high scope of investment protection to the customers of financial institutions. Precisely in this context one should underline the most essential obligations of financial institutions, incorporating such issues as: the scope of information to be made available to customers, the preparation of systemic solutions concerning the so-called good practice of order fulfillment, the principles of management of conflict of interest, and the methods of customer insight/assessment by introducing the so-called suitability and appropriateness/adequacy tests. It should be stressed here that precisely these issues are underlined in the information package requiring to be provided by financial institutions operating on the Polish market for financial services. ${ }^{9}$

Monitor Polski, No. 46, item 683

As an example, here one may refer to the information materials prepared by: Raiffeisen Bank S.A." - MiFID information brochure for customers of Raiffeisen Bank Polska S.A."; Bank BGŻ S.A.- Information about MiFID; BPS 
Prior to the commencement of the analysis of specified amendments, it is necessary to determine the products offered by financial institutions, to which the new regulations shall apply. Art. 2.1 of the $\mathrm{Law}^{10}$ introduces the uniform definition of the financial instrument, within which two categories may be specified. The first category incorporates securities, i.e. stocks and bonds. The second category includes share units (which are not securities), money market instruments, options, futures contracts, swaps, forwards, and other derivatives.

MiFID makes the scope of customer protection conditional on the classification category of the customer. This places an obligation on financial institutions to make classification (segmentation) of their customers on the basis of definitions mentioned in the legal act. ${ }^{11}$ In Art. 3.39, the lawmaker introduced a negative definition for the most numerous group of customers, indicating that a retail customer shall be the entity, who is not a professional customer ${ }^{12}$ in whose favor a minimum of one service - relating to acceptance and fulfillment of orders, the service of keeping and the service of registration of financial instruments, and investment advice - is being provided. This manner of definition causes the necessity to precisely determine the category of the "professional customer", which category is quite broad. Speaking generally, given the provisions of Art. 3.39.b of the Law, ${ }^{13}$ one may assume that the lawmakers in this category, - apart from financial institutions, such as banks, insurance institutions, investment and pension funds, and public administration units - included entrepreneurs who meet a minimum of two of the three criteria required: balance sheet total, value of income from sale, amount of equity capital. ${ }^{14}$

In terms of legislation, the third category, i.e. "an authorized contractor" may cause doubts. The Polish lawmakers, after all, in line with the European regulations ${ }^{15}$ did not place this category under the legal definition of customers, Art. 3 of the law. ${ }^{16}$ These definitions, however, can be found in the secondary legislation, i.e. in $\S 7.1$ of the Minister of Finance's Ordinance, ${ }^{17}$ pursuant to which the customer, being

S.A.- MiFID information brochure; Guide for the Customer and PKO BP S.A. -Information brochure on MiFID requirements with regard to the Customers of Powszechna Kasa Oszczędności Banku Polskiego Spółki Akcyjnej. (Journal of Laws 2009, No. 165, item 1316)

11 See above

12 The Directive introduced the category of a "trade customer" - Directive 2004/39/EU of the European Parliament and of the Council on markets in financial instruments..., Official Journal L 145, 30/04/2004 P. 0001-0044.

13 Journal of Laws 2009 , No. 165 , item 1316

14 In accordance with Art. 3.39.b, the criteria are as follows: the balance sheet total at the level of a minimum of EUR 20000 000, the value of income from sale at the level of a minimum of EUR 40000000 , entrepreneur's equity capital at the level of a minimum of EUR 2000000 , Journal of Laws 2009, No. 165, item 1316. 09/08/2007 L 209, Supplement No. 38.

16 Journal of Laws 2009 , No. 165 , item 1316

17 Finance Minister's ordinance of 20 November 2009 on the manner and conditions of conduct of investment firms, banks, referred to in Art. 70.2 of the Trading in Financial Instruments Act, and of custodian banks, Journal of Laws 2009 No. 204 item 1577 
a financial institution, ${ }^{18}$ to whom another investment firm renders services, is an authorized contractor. Therefore, it is a category of professional customers operating in the financial sector, with regard to whom, it is assumed that they have amassed experience that makes it possible for them to make investment decisions on the basis of their corporate profile. For this category of customers the lowest protection is stipulated, which protection incorporates only the transfer of necessary information documenting the implemented transactions, which is to be discussed herein below. This legislative measure, however may cause doubts in terms of the purposefulness of defining this group of customers at the level of the secondary legislation. ${ }^{19}$

Analyzing the issues relating to the classification (segmentation) of customers, it is also necessary to underline special situations, i.e. an opportunity to re-classify a given customer and the given customer's migration between specified categories. We will deal with the first situation inter alia when the customer, despite his failure to meet statutory prerequisites, will forward a written request to classify him as a professional customer. Here, however, an obligation was imposed on the investment firm to establish whether the customer applying for the change of category, possesses the knowledge and experience necessary for making proper investment decisions, including, in particular, whether the customer can make risk assessment. This risk assessment may be supported by the presumption contained in $\S 5.1$ of the Minister of Finance's Ordinance, ${ }^{20}$ according to which the condition to have knowledge is deemed satisfied, if the customer meets a minimum of two of the following requirements: if the customer makes transactions valued at a minimum of the PLN equivalent of EUR 50000 per transaction on the relevant market with an average frequency of a minimum of 10 transactions per quarter during the last four quarters; if the value of the customer' portfolio of financial instruments, including currency, amounts to a minimum of the PLN equivalent of EUR 500000 , or the customer operates or will operate (if at all) in the financial sector during a minimum of one year in a position requiring specialist knowledge about financial instruments. Undoubtedly, the customer applying for such re-classification shall prove the circumstances, to which he referred, by submitting proof of concluded transactions, the condition of assets or an employment agreement (employment certificate) certifying the scope of duties performed. In addition, the customer of the financial institution, applying for placement in the category of professional customers, shall, in accordance with the provisions of $\S 5.5$ of the Minister of Finance's Ordinance, ${ }^{21}$ make a statement to certify that he has knowledge of the principles of how such

This provision refers to Art. 3.39.b of the law, incorporating into this group, inter alia, banks, investment firms, investment funds / investment companies and pension funds / pension companies, Journal of Laws 2009, No. 165, item 1316.

19 Journal of Laws 2009 No. 204 item 1577.

20 See above.

21 See above 
customer is treated. The investment firm, however, shall notify the customer about these principles.

The provisions of Art. 3.a).2 of the Law, ${ }^{22}$ stipulate an opportunity for the professional customer to apply for his classification to a category, which is covered by the broadest protection, i.e. as a retail customer. Given this provision, doubts may arise of whether the investment firm is obliged or solely authorized to make this reclassification. Taking into account the wording of $\S 5.1$, in conjunction with $\S 3.1$ and $\S 3.2$ of the Minister of Finance's Ordinance, ${ }^{23}$ the first option is rather a must.

Second, it is necessary to present an opportunity arising from the wording of provisions of $\S 6.3$ and $\S 7.5$ of the Ordinance ${ }^{24}$ on the basis of which the financial institution will also be authorized to make an independent re-classification of the customer based on obtained information. ${ }^{25}$

This being the case, certain doubts may arise from the fact that all variants of re-classification of customers (at the financial institutions' initiative) have been regulated, except for the case when the existing retail customer begins to meet the requirements of a higher category. It is, however, necessary to admit that in this case re-classification may be made with a reservation to the effect that the customer will be notified of the option to remain in the "retail customer" category and will not take advantage of the opportunity. ${ }^{26}$

It is necessary to stress that basic differences between the scope of information obligation may be seen only between the category of retail customers and the category of authorized contractors. The financial institution, on the basis of $\S 7.1$ of the Minister of Finance's Ordinance, ${ }^{27}$ may limit, toward authorized contractors, its obligation to make information available (apart from the basic data concerning a given transaction) to the transfer of the principles of management of conflict of interest and the individual notification to a given customer concerning a case of a materialized conflict of interest. With regard, however, to the information obligation toward retail customers and professional customers, one may assume that this obligation is very similar. This latter obligation incorporates the information

Journal of Laws 2009 r. No 165 , item 1316.

Journal of Laws 2009 No. 204, item 1577

See above.

Given these provisions, at issue are the cases of re-classification in order to increase the protection. It is however possible to assume that if the financial institution obtains the formal basis (on the grounds of updated documentation) for the re-classification of the customer to a lower protection category, said re-classification is also admissible, undoubtedly against the prior written notification of the customer, who may also request that he be classified as before.

This is the a contrario application on the basis of the provisions of $\S 3$ of the Finance Minister's Ordinance of 20 November 2009, on the manner and conditions of conduct of investment firms. As the potential customer may take advantage of an opportunity to be treated as a retail customer (despite the fact that he meets the criteria for being classified as a professional customer), there are no grounds to turn down the rights of the customer, who is serviced by the classification-making institution. Journal of Laws 2009 No. 204 item 1577. 
of a general nature concerning the principles of management of a conflict of interest and the principles of operation in the best interest of the customer during the performance of the order. ${ }^{28}$ In addition, the information characterizing specified financial instruments, with a detailed specification of types of risks related thereto, and the general information about the financial institution shall be conveyed. ${ }^{29}$

From the viewpoint of the protection of customer interests, particularly essential is the information concerning the description of the financial instrument and the risks related thereto, which shall be communicated to the customer so that the customer, taking into account his profile (category), will be able to understand the essence of the product and the risks involved. The Minister of Finance in $\S 13$ of his Ordinance ${ }^{30}$ expressly defined this requirement and stressed that the scope of this information shall enable the customer to take responsible investment decisions, including the specification of the risk related to a given type of financial instruments (inclusive of an explanation of the term 'financial lever'), the feature of changeability of the price of these instruments, any limitations in their availability on the market, the scope of contracted financial obligations, and insurance requirements (if any). Although the contents of sec. 3 of this paragraph show that it is possible (with regard to a financial instrument being the subject-matter of a public offer) to refer the customer to the prospectus, taking into account the scope of required information and, in particular, the manner of its formulation as adjusted to a given group of customers, it is necessary to admit that this obligation will be of a practical importance due to the complex nature of contemporary financial instruments.

Given this aspect, it is also worth emphasizing the requirements concerning the information which is being made available to customers under cover of an advertisement. In accordance with $\S 9$ of the Ordinance, ${ }^{31}$ this type of information, which is made available by the investment firm, shall be "reliable, unquestionable and not misleading" and shall stress that it is made available for the purpose of advertising or promotion of services. In particular, the advertisement, which is forwarded to retail customers, must not conceal (decrease) the risks, which accompany the financial instrument being offered. If comparisons to other products or simulations are applied, they shall be: authoritative, reliably presented, indicate the source of their origin, and include a statement to the effect that they are being

$\S 48,52$, Journal of Laws 2009 No. 204 item 1577.

The purposefulness of limitation solely to retail customers of the general information concerning the investment firm itself, e.g. the name of the firm, contact data, the confirmation that the company holds permissions issued by supervisory authorities, detailed principles of service provision, operations through an agent (if any), the principles of submission and administration of customers' complaints may cause doubts. This is not quite understandable, because these are the basic data, which, in accordance with $\S 11.2$ of the above-mentioned Ordinance, the investment firm may place (and most often it does) on its webpage, access to which is open to all categories of customers.

30 Journal of Laws 2009 No. 204 item 1577 
used for comparative purposes. In addition, the main facts and assumptions that were used for comparison shall also be specified. ${ }^{32}$

Taking into account the scope of information that is made available to customers, it is worth considering here the internal procedures, which the financial institution is obliged to implement and convey to the customers as part of the information package. They concern two aspects, i.e. the principles of operation in the best interest of the customer while fulfilling the order and the principles of management of conflicts of interest.

The financial institutions' obligation to prepare, implement and apply the procedure (often referred to as the policy), which determines the principles of order fulfillment, arises from the second part of the Ordinance ${ }^{33}$ titled "the obligation to act on conditions which are most beneficial for the customer". In accordance with $\S 48.1$ of the Ordinance, ${ }^{34}$ the financial institution is obliged to implement and apply the solutions, which ensure operations in the best interest of the customer. However, the preceding provision of $\S 47.1$ of the Ordinance ${ }^{35}$ stresses that the company providing investment services is obliged to take "all reasonable acts in order to achieve the best possible results for the customer in connection with the order fulfillment". Undoubtedly, this definition is very general, therefore, to be effective (enforceable), in the subsequent part of this provision it was made more precise by indicating the criteria by which the investment firm shall be guided. These will be the following factors: the price of a given financial instrument, the costs related to the order performance, the size of the order (the nature thereof), the time of the transaction implementation, the probability of its conclusion (including the settlement), and other factors, which may exert an essential impact on the achievement of the best economic effect from the provision of investment services. ${ }^{36}$

The scope of transferred information will differ depending on the category of the customer classification. In case of a retail customer, the investment firm, within the framework of the order fulfillment policy, is obliged to provide the description of the importance attributed to specified factors and a list of places where the order will be fulfilled. The retail customer shall also receive the warning, in an express and unequivocal manner, that the customer's detailed conditions of the order fulfillment

This Ordinance regulates these issues in a very detailed manner. Even the time-period (5 years) to present the results is specified. In case of the above-mentioned simulations of the results to be obtained in the future or the projections of potential profit, detailed information/warning in this scope shall be included. Journal of Laws 2009 No. 204 item 1577

See above.

$\S 47$, see above.

Due to the general nature of the latter criterion, it is essential to provide as many details as possible, in accordance with provisions of $\S \S 51.2-51.3$ of the Ordinance, according to which this obligation does not mean the necessity to include into the policy of acting in the best interest of the customer all possible places where the order may be fulfilled. The criterion however is deemed to be satisfied, if the existence of more than one place of fulfillment is considered, Journal of Laws 2009 No. 204 item 1577. 
coul d make it impossible for the service provider to act in the direction of achievement of the best possible results. The crucial criteria, however, in the assessment of the customer order fulfillment will be as follows: the price of the financial instrument and all costs related to the implementation of the transaction. ${ }^{37}$

Another obligation is to inform the customer of the issues related to conflicts of interest. The necessity to draw up and implement procedures in this scope was imposed on the investment institutions by the provisions of $\S 3.1$ of the Minister of Finance's Ordinance of 23 November 2009, on determination of detailed technical and organizational conditions for investment firms, banks, referred to in Art. 70.2 of the Trading in Financial Instruments Act, and for custodian banks, as well on conditions of brokerage house's evaluation of the internal capital. ${ }^{38}$ Pursuant to these provisions, the task of the internal procedure regulating the issues connected with conflicts of interest is, first, to specify the acts to be taken by the investment institution in order to eliminate cases of conflicts of interest. Second, in case of the occurrence of this situation, the customer shall be notified about the emergence of the conflict so that the customer could take a responsible decision on whether or not to use the services of a given company prior to the conclusion of the agreement. ${ }^{39}$ The above-mentioned ordinance determines in a quite precise way the contents of the procedure aimed at working against and managing conflicts of interest. Prior to describing these conflicts of interest, it is first necessary to define the term 'conflict of interest' and the situation in which it could emerge. This definition is based on the Minister of Finance's Ordinance, which has already been referred to hereinabove, ${ }^{40}$ pursuant to which, conflict of interest shall mean the circumstances which could cause disagreement between the interest of the investment firm or of a person connected with the investment firm and its obligation to act for the customer in a reliable manner, guided by both the best interest of the customer and any circumstances of which the investment firm is aware which may lead to disagreement between the interests of several customers of the investment firm. The circumstances that may cause this conflict of interest were provided on the bas is of an open catalogue.

First, it will be a situation where the investment firm or a person connected with the investment firm could derive benefit or avoid loss due to its customer(s) suffering loss or not deriving any benefit. Second, when the investment firm or person connected with the investment firm has reasons to apply preferences toward a given customer (or group of customers). Third, the conflict of interest will occur

$\S 48$ item 4 , see above.

Minister of Finance's Ordinance of 23 November 2009, on determination of detailed technical and organizational conditions for investment firms, banks, referred to in Art. 70.2 of the Trading in Financial Instruments Act, and for custodian banks, as well on conditions of brokerage house's evaluation of the internal capital, Journal of Laws 2009 No. 204, item 1579.

$\S 23.1$, Journal of Laws 2009 No. 204, item 1577

$\S 23$ items 2,3 Journal of Laws 2009 No. 204 item 1577. 
in a situation where the investment firm or person connected with the investment firm is interested in a specified result of the provided service, which result conflicts with the customer's best interests. Four, in the situation where the financial gain was received from a third party. Undoubtedly, it should be emphasized that at issue here is not regular fees and charges that constitute the consideration for the provided service. The final and the simplest situation for identification is when the investment firm or person connected with the investment firm, carries out economic activity that is analogical to its customers' activity. With a view to systematizing all possible situations of conflicts of interest, it is possible to determine three lines (relations), along which conflicts of interest can occur: disagreement between the interest of the financial institution and the interest of the customer(s) disagreement between the interest of the customer or group of customers and the interest of another customer or group of customers, disagreement between the interest of the financial institution and/or its customers and the interests of an individual or group of individuals in the financial institution's employ.

If we return to the issues, which shall be determined in the internal procedure aimed at counteracting the occurrence of conflicts of interest, the Minister of F inance underlined certain minimum requirements, which said internal procedure shall incorporate. In particular, the situations, which may generate the crucial risk of customer interests violation as well as the actions aimed at the management of conflicts of interest in case of their occurrence, shall be specified (identified). In order to generalize these actions, one may assume that at issue is, first, the performance of adequate official supervision of the persons who, due to their fundamental obligations, may cause conflict to occur. However, it is also necessary to admit that this, in particular, concerns the current supervision over employees in terms of official hierarchy as well as control of the actions implemented by entities responsible for internal control procedures. Second, these will be actions meant to manage the conflicts of interest. These actions may be referred to as organizational actions connected with the remuneration of the financial institution employees, the elimination of the impact of third parties, and the proper determination of the scope of financial institution employees' obligations.

Within the framework of obligations related to the management of conflicts of interest, the investment firm is also obliged to maintain a register of types of activity which have already caused, or which could cause, conflicts of interest to arise.

Summarizing the above, it is necessary to emphasize here that the obligation to draw up, implement, and apply procedures concerning conflict of interest involves all categories of customers, and, therefore, authorized contractors.

On par with the above-mentioned information obligations - which address the financial institution customers and the prerequisite actions needed to provide services 
properly, reliably and fairly - it is also necessary to stress here the obligations related to the collection of information about customers and the verification of their knowledge in the scope and use of financial services, i.e. the conduct of the so-called suitability and appropriateness/adequacy tests. Apart from the obligation to provide information, this is, so to speak, the second key element in meeting conditions for the implementation of MiFID objectives.

At first, a certain inaccuracy of a legislative nature emerges here, which is materialized in two aspects. First, the terminology concerning the conduct of these tests is not quite coherent. If the Directive41 in Art. 36 applies the definition of "general appropriateness/adequacy", in Polish legislation these categories shall be derived from the provisions of $\S 15$ of the Minister of Finance's Ordinance. ${ }^{42}$ Both regulations, however, lack the express differentiation of issues, which fall under assessment of the so-called suitability and appropriateness/adequacy tests. This circumstance gains even a greater importance, as in accordance with the provisions of $\S 18$ of the Ordinance, ${ }^{43}$ the investment firm may withdraw from the assessment of customers, who have been placed in the professional customers category ${ }^{44}$ in terms of their knowledge about financial instruments and investment experience.

In practice, both the suitability test and the appropriateness/adequacy test, will be made on the basis of the study of customers' questionnaires. This being the case, the objective of the appropriateness/adequacy test is to examine the customer's level of knowledge (one may say, of general knowledge) about financial services and financial instruments. On the basis of the test, the investment firm will analyze the customer's level of knowledge and will specify a group of financial instruments with similar features (including, a similar level of risk), which could be suitable for a given customer. As a result, within the framework of one and the same test, the customer may expect questions about the financial services and financial instruments, of which he is aware, about the scope of current use of said financial services and instrument and about the frequency of this use. In addition, there could be questions about the level of education and the profession practiced. ${ }^{45}$

In respect the suitability test, one shall assume that its objective is to examine the customer's individual situation in a detailed and precise manner. To carry out the suitability test, the investment firm shall obtain information about the customer's

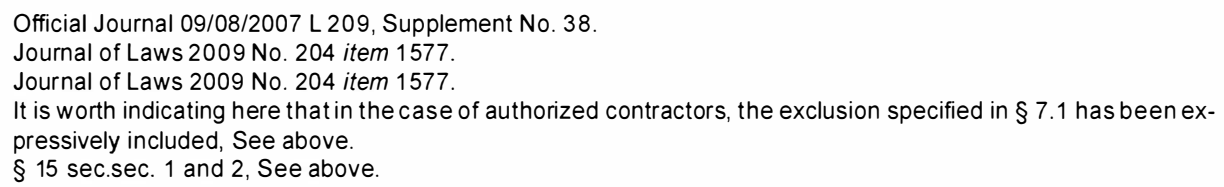


financial situation and the sources and the level of "permanent income, assets possessed, investments, real properties and permanent financial liabilities". ${ }^{46}$

In addition, the information shall also incorporate "the length of the period during which the customer would like to make investments, his preferences with regard to the level of risk, the profile of risk, and the objective of the investment". ${ }^{47}$

On the basis of the suitability test, the investment firm is obliged to specify whether, taking into account the nature and the scope of rendered service, a given transaction - which is recommended to the customer or which is being implemented (i.e. the service is being provided) - meets the customer's investment objectives and whether the structure of this transaction is understandable to the customer, due to which understanding, the customer can appropriately assess the level of risk and can decide whether this level of risk is acceptable. The issue of risk is particularly emphasized here, given the edited version of $\S 16.2$ of the Ordinance, ${ }^{48}$ in accordance with which the investment firm is obliged to specify the level of acceptability of risk by a given customer and at the same time shall determine that this risk is properly understood (i.e. assessed) by the customer.

Unfortunately, apart from this information, the investment firm was made responsible to again examine the level of customer's knowledge about the investment in financial instruments and the customer's investment experience. This approach shall be assessed negatively, as on the one hand, the optionality of data collection and customer examination is emphasized ( $(18.1)$, while on the other hand, the obligation is imposed to examine these issues under pain of refusal to provide services $(\S 16.5 .1) .{ }^{49}$ Doubts in this scope also arise on the basis of $\S 20.1$, pursuant to which the investment firm may not conduct the appropriateness/adequacy test in case of provision of services consisting in performance or acceptance of orders, on condition that these orders concern uncomplicated financial instruments, ${ }^{50}$ that the

In this instance an unclear legislative measure is applied. On the one hand, in sec. 16.3, it is stressed that the investment firm, in case of need, may request that the customer provides the data about his permanent income, investment, real properties, and liabilities, while on the other hand, in sec. 5 , the consequences of the refusal to render the service in the case of lack of data about the customer's financial situation, are emphasized. Here a rhetorical question arises: how can the customer's financial situation be established if there are no data on precisely the amount and sources of income, investments, liabilities, etc. This means that these data will be required not only on the "if-necessary" basis, but also in each situation. If the objective of this regulation is to provide some space for the financial institution's decision-making process, the specification of data which the financial institution has to obtain from the customer in order to assess his financial situation - is not required in this case. The financial situation will be assessed in a standard manner, Journal of Laws 2009 No. 204 item 1577.

The remark on the financial institution's search for the information to make it possible to specify the customer's investment objectives is analogical to the above remark concerning the data required to determine the customer's individual financial situation. Journal of Laws 2009 No. 204 item 1577

See above.

The definition of the uncomplicated instrument is provided in $\S 20.2$, pursuant to which this term shall mean: 1) shares/stock admitted for trading on a regulated market or on an equivalent market in a state, which is not a member-state; 2 ) bonds or other securities which do not have embedded derivatives; 3 ) share units of investment funds, titles of participation in foreign funds and titles of participation in open investment funds with registe- 
conclusion of the agreement for provision of services was initiated by the customer, who had been warned by the investment firm to the effect that the obligation to make this assessment is not being realized and for this reason the customer will not enjoy protection in this scope. There is also a requirement in this scope to the effect that the financial institution shall maintain and apply procedures concerning the conflict of interest.

As stated above, this means that in practice investment firms (in quite a few cases) will be able not to conduct the adequacy test as an individual act (on the basis of study of customers' questionnaires), while at the same time investment firms will be obliged to make this assessment within the suitability test framework, of course, with the exclusion of customers placed in the category of authorized contractors.

The assumption is that the assessment made by the investment firm shall be used as the basis for the individual analysis of a given customer. On the basis of this analysis, the investment firm may take up actions of two types. With regard to a given financial instrument, the investment firm is obliged to warn the customer that a given financial instrument or service is improper for him. ${ }^{51}$ In addition, analyzing the entire situation, the investment firm may recommend that the customer modifies his investment strategy. ${ }^{52}$

Undoubtedly, the financial institution may solely suggest (recommend) specified action, which may subsequently be ignored by the customer. The fulfillment of these obligations, however, causes that the customer makes his investment decision on the basis of knowledge in the scope of a given financial instrument and is fully aware of the risk specified.

\section{Summary}

Consistent with the opening statement of this article, the Directive regulates a wide scope of issues related to the operations of financial institutions. Therefore, it would seem appropriate at this stage to view them from the customers' standpoint and, from that perspective, to address the most essential amendments and their

red offices in the states that are members of the European Economic Area and open investment funds with registered offices in states that are members of OECD, other than member states or the states that are members of the European Economic Area and 4) financial instruments, other than mentioned in Art. 2.1.2 c) - i) of the Law: a) which can, on a permanent basis, be disposed of, bought out or sold in any other manner for the instrument value at a price, which is generally affordable for the market participants and which is the market price or a price established or confirmed by the valuation system, which is independent from the issuer of given financial instruments, b) with which customer's actual or potential liabilities - exceeding the purchase cost of these instruments - are not connected, $c$ ) with regard to which there exists publicly available information explaining their characteristics in manner, which is understandable to the customer, Journal of Laws 2009 No. 204 item 1577. 
consequences in relation to the scope of standards (currently binding in Poland) effecting the implementation of financial services. Taking into consideration the obligations imposed in this scope on financial institutions, the statement to the effect that the new regulation will lead to raising standards on the market for financial services in the scope of protecting customer interests seems to be justified. This is despite the fact that the applied criteria of division (segmentation) of customers causes a quite flat structure thereof. As a result, a prevailing majority will be retail customers on par with a less frequent group of professional customers, among which a group of entities providing services on the financial market -i.e. authorized contractors - will be expressly separated. This, however, does not change the fact that customers will receive information about financial instruments (the essence thereof) in a much wider scope, with a special accent on investment risks related thereto, because at issue here is the customer's ability to make an informed and responsible decision. Also of essence here, are the additional details imposing the obligation to explain such terms as: the financial lever, the features of changeability in the price of these instruments, any limitations in their availability on the market, the scope of contracted financial obligations, and insurance requirements (if any).$^{53}$ It is necessary to stress here that the way of formulation of this information shall also be adjusted to the customer, who is the addressee thereof. These circumstances are of a particular importance, if we take into consideration the complex nature of contemporary financial instruments. It is worth emphasizing here that information obligations were also determined in the aspect of advertisements, which shall not conceal (decrease) the risks related to a given instrument. All comparisons, simulations and analyses placed in advertisements shall be reliable and trustworthy.

The obligations in the scope of the financial institutions' introduction of internal regulations concerning the management of conflict of interest and the principles of conduct in the best interest of the customer, are important here as well. On the one hand, these regulations should be regarded as the information obligation toward the customer. On the other hand, however, the introduction of this type of procedure could have an impact on the reliability of services rendered and on the customer's opportunity to assess them, given elimination of the situation threatening the objectivism of the service provider (the financial institution).

Apart from information obligations, it is finally necessary to mention activities, which financial institutions will be obliged to undertake in order to analyze and assess its specified customers. At issue here, is the assessment of suitability and appropriateness/adequacy. Disregarding the fact that the separation of these two assessments and the necessity to carry them out was specified in a doubt-raising manner, it is necessary to admit that the change consisting in the introduction of 
the obligation to examine and assess the customer's general knowledge as well as to determine the customer's individual expectations with regard to a given financial instrument, is profound and positive. Besides, the consequences of this assessment consisting in the preparation of recommendations by the investment firm both in the scope of a given service and the customer's entire investment strategy are also important.

Summarizing the above, one should admit that obligations stemming from the transposition of the new regulation to the Polish regulatory framework, may influence the level of customer protection on the market in financial services. At the same time, it is necessary to stress that apart from a quite precise definition of new obligations, the genuine scale of their effect will to a greater degree be determined by the quality of relevant internal regulations formulated by financial institutions and by the meticulousness of their application. As a result, only a well-shaped practice will show the scale of positive changes. A special role (particularly in the initial period) will be played by the Financial Supervision Authority, which during the inspection of specified financial institutions will be obliged to verify in detail the correctness and the feasibility of these procedures. The meticulousness of these inspections will be exceptionally important for the implementation of the objective of the new regulation, including in particular, for the elimination of risk relating to the apparent nature and character of changes accepted by specified financial institutions. However, referring to the issue raised at the outset of this article, it is necessary to admit that had the new regulation been transposed earlier, it could have somewhat limited the losses of Polish entrepreneurs, who suffered losses from the application of the so-called FX/currency options, in particular, those Polish entrepreneurs, who were the customers of banks in which Polish capital held a majority stake and which banks had not yet introduced MiFID. It is, however, genuinely difficult to assess the scale by which the losses suffered could have been avoided. 


\section{SELECTED ISSUES RESULTING FROM THE IMPLEMENTATION \\ OF THE MARKETS IN FINANCIAL INSTRUMENTS DIRECTIVE OF THE EUROPEAN PARLIAMENT AND OF THE COUNCIL (MIFID) IN THE POLISH REGULATORY FRAMEWORK}

The regulations for standardization of operations of the markets in financial instruments (MiFID) is a new regulation which has been in effect in Poland from this year and is gaining a specific importance in terms of reality, taking into account the difficulties which, in connection with the world economic crisis, some entrepreneurs, who trade in FX derivatives have experienced.

It is necessary to raise here a proposal, which will form the basic assumption of this article, i.e. the solutions introduced could provide an increase in the protection afforded to customers in the market in financial instruments. It is, however, necessary to stress that the protection of customers in the market in financial instruments is being implemented comprehensively, because the assumption of said regulation is the establishment of an unified legal framework for financial markets that operates within the framework of the EU member-states, together with Iceland, Norway, and Lichtenstein. The directive introduces standards to such issues as: conditions of activity related to a businesses' provision of investment services (also including additional services), organization of financial institutions, requirements concerning their reporting and the principles of transaction transparency.

New obligations imposed on financial institutions will be divided into three categories. The first category will incorporate problems related to the classification (segmentation) of new and existing customers. Thereafter, the issues related to information obligations, also including procedures followed as early as on the stage of commencement and provision of services, will be presented. Finally, obligations of the individual analysis and customer evaluation will be indicated.

At the same time, it is necessary to stress that apart from a quite precise definition of new obligations, the genuine scale of their effects will to a great degree be determined by the quality of relevant internal regulations formulated by financial institutions and by the meticulousness of their application. As a result, only a wellshaped practice will show the scale of positive changes. A special role (particularly, in the initial period) will be played by the Financial Supervision Authority, which during the inspection of specified financial institutions will be obliged to verify in detail the correctness and feasibility of these procedures.

Key words: MiFID, FX derivatives, customer, financial market, Financial Supervision Authority 


\section{NOWE OBOWIAZZKI DLA SEKTORA BANKOWEGO WYNIKAJĄCE Z IMPLEMENTACJI REGULACJI EUROPEJSKICH}

Regulacja dotycząca standaryzacji funkcjonowania rynków instrumentów finansowych (MiFID) wprowadzona została w Polsce w kwietniu 2010 r. i zyskuje w naszych realiach na znaczeniu, biorąc pod uwagę trudności, które w związku z kryzysem światowym dotykają niektórych polskich przedsiębiorców.

W tym miejscu konieczne jest postawienie tezy, która stanowi podstawowe założenie przyjęte w niniejszym artykule, stąd - wprowadzone rozwiązania mogą spowodować wzrost ochrony klientów na rynku instrumentów finansowych.

Należy podkreślić, że ochrona klientów na rynku instrumentów finansowych jest wdrażana kompleksowo, ponieważ założeniem wspomnianej regulacji jest ustanowienie jednolitych ram prawnych w zakresie rynków finansowych, które działaja w ramach Państw Członkowskich UE, Islandii, Norwegii i Lichtensteinu.

Dyrektywa wprowadza standardy między innymi dotyczące: organizacji instytucji finansowych, wymogów dotyczących ich kontroli i zasad odnoszących się do przejrzystości transakcji.

Nowe obowiązki nakładane na instytucje finansowe można podzielić na trzy kategorie. Pierwsza kategoria dotyczy problemów związanych z klasyfikacją (segmentacja) nowych i obecnych klientów. W następnej mieszczą się kwestie obowiązków informacyjnych, również $w$ sferze procedur stosowanych $w$ jak najwcześniejszym stadium współpracy z klientem. W końcu, w trzeciej z nich są obowiązki dotyczące indywidualnej analizy i oceny klienta.

Na podkreślenie zasługuje to, że abstrahując od dość precyzyjnej definicji nowych obowiązków, prawdziwa skala skutków ich realizacji będzie w dużym stopniu zdeterminowana jakością odpowiednich przepisów wewnętrznych przyjętych przez instytucje finansowe i skrupulatnością ich stosowania. W efekcie, tylko dobrze ukształtowana praktyka pokaże skalę pozytywnych zmian. Szczególną rolę (w szczególności w okresie początkowym) będzie odgrywała Komisja Nadzoru Finansowego, która podczas kontroli określonych instytucji finansowych będzie zobligowana do szczegółowego sprawdzenia prawidłowości i wykonalności tych procedur. 